\title{
A taxonomic revision of the small Cape genus Steirodiscus (Asteraceae: Senecioneae)
}

\author{
J.C. MANNING ${ }^{1,2}$;P. GOLDBLATT ${ }^{2,3}$ and L. JOUBERT ${ }^{4}$
}

Keywords: Asteraceae, Senecioneae, Steirodiscus Less., southern Africa, taxonomy

\section{ABSTRACT}

\begin{abstract}
The genus Steirodiscus Less. is revised, with full descriptions, nomenclature, illustrations and distribution data. Five species are recognised in two sections: sect. Steirodiscus with free involucral bracts and sect. Psilothonna with bracts connate into a smooth cup. S. linearilobus DC. is established as an earlier name for S. schlechteri Bolus, which is relegated to synonomy.
\end{abstract}

\section{INTRODUCTION}

Steirodiscus Less. is a minor genus of Senecioneae comprising five species of small, wiry annuals, all endemic to the Greater Cape Floristic Region (Goldblatt \& Manning 2000; Herman et al. 2000). Currently included in subtribe Senecioninae (Pelser et al. 2010), its relationships within the subtribe are still unclear (Nordenstam et al. 2009). Although treated as one of the 'othonnoid' genera by Jeffrey (1992) on account of its ebracteolate and sometimes gamophyllous involucre, molecular data place it among the group of genera that includes Bolandia Cron, Cineraria L., Emilia Cass., Mesogramma DC. and Stilpnogyne DC., rather than with the Othonninae (Nordenstam et al. 2009; Pelser et al. 2010). A recent phylogenetic analysis of plastid and nuclear sequence data identifies Steirodiscus as one of several lineages with strongly incongruent positions in the two analyses (Pelser et al. 2010). Hybridization and incomplete lineage sorting were suggested as explanations for the incongruence.

Steirodiscus was established by Lessing (1832) to accommodate the species described by Linnaeus fil. (1782) as Cineraria capillacea, and was originally characterised by a uniseriate involucre of free bracts without associated bracteoles, female ray florets with pubescent cypselas, and male-fertile disc florets. At the same time Lessing (1832) also recognised the genus Gamolepis for four shrubby Cape species now treated in Euryops plus the solitary annual species Othonna tagetes L. (under the illegitimate superfluous name Gamolepis annua Less.), which were linked by their smooth, cup-shaped involucres, female ray and bisexual disc florets, and epappose cypselas.

\footnotetext{
${ }^{1}$ Compton Herbarium, South African National Biodiversity Institute, Private Bag X7, Claremont 7735, South Africa. E-mail: J.Manning@ sanbi.org.za.

${ }^{2}$ Research Centre for Plant Growth and Development, School of Life Sciences, University of KwaZulu-Natal, Pietermaritzburg, Private Bag X01, Scottsville 3209, South Africa.

${ }^{3}$ B.A. Krukoff Curator of African Botany, Missouri Botanical Garden, P.O. Box 299, St. Louis, Missouri 63166, USA. E-mail: peter.goldblatt@mobot.org.

${ }^{4}$ Geo Potts Herbarium, P.O. Box 339, Bloemfontein 9300, South Africa. E-mail: JoubertL@ufs.ac.za.

MS. received: 2013-01-17.
}

These generic circumscriptions were followed by Candolle (1838), who added a second species, Steirodiscus linearilobus DC. The sole annual species of Gamolepis, G. tagetes (L.) DC., which had by then been selected as the lectotype of the genus (Pfeiffer 1874), was subsequently transferred to Steirodiscus by Schlechter (1899), who was struck by its marked similarity to that genus in habit, finely dissected leaves and epappose cypselas, despite the marked difference in their involucres. At this time two further species were described, S. gamolepis Bolus and S. schlechteri Bolus (Schlechter 1899), bringing the total in the genus to five. A sixth species [now S. speciosus (Pillans) B.Nord.] was later named by Pillans (1931) under the generic name Gamolepis.

Steirodiscus is defined by its annual habit, pinnatisect or bipinnatisect leaves with subsecund, linear-filiform segments, and solitary or laxly corymbose, radiate capitula with unseriate, ebracteolate involucre, and all florets lacking a pappus. The involucral bracts may be free or connate into a smooth cup. The generic name is derived from the sterility of the disc florets in S. capillaceus (Lessing 1832), but this condition is not easily assessed in flowering capitula as maturation of the central florets is tardy. We have confirmed that the central disc florets in S. tagetes fail to develop fruit but whether this is due to congenital sterility or to nutritional constraints we cannot say. This will need to be assessed through careful anatomical investigation for the presence or absence of an embryo in the central disc florets.

A brief review of the group under the illegitimate superfluous generic name Psilothonna (E.Mey. ex DC.) E.P.Phillips (Nordenstam 1968) was presented by Phillips (1950), who also provided a key to the five species recognised. This review, although based on very few collections, provided some much-needed clarity in the genus but Phillips (1950) inexplicably overlooked Candolle's (1838) S. linearilobus. This name was applied (incorrectly as we show below) by Hutchinson (1946) to plants from the Klein Roggeveld and the species has remained poorly understood until now.

Five names in Steirodiscus are included in the Red List of South African Plants (Raimondo 2009), four as either EN or VU and S. linearilobus as DD signifying its uncertain identity. At the moment therefore, although 
six names are validly published in the genus, only five species are accepted (Goldblatt \& Manning 2000). The genus is urgently in need of revision, not only to establish the number of recognised species and the application of the available names, but also the distribution and thus conservation status of the taxa. Three of the species (S. gamolepis, S. linearilobus and S. speciosus) are highly localised endemics and another (S. tagetes) is restricted to the West Coast, where it is evidently already extinct from part of its range and threatened by coastal development elsewhere. The fifth species ( $S$. capillaceus), although relatively widespread, has not been recorded from most of its historical range for over 50 years.

We provide a complete taxonomic revision of Steirodiscus, including full descriptions and synonymy, illustrations and distribution data for all species. The species fall into two groups depending on whether the involucral bracts are free to the base or connate into a smooth cup, which we treat as the sections Steirodiscus and Psilothonna respectively.

\section{MATERIALS AND METHODS}

Specimens or digital images of all relevant types were examined, as well as all herbarium material from BOL, NBG, PRE and SAM (acronyms after Holmgren et al. 1990), the primary collections of species from southern Africa. All species were also located and studied in the field.

\section{TAXONOMY}

Steirodiscus Less., Synopsis generum Compositarum: 251 (1832). Type species: S. capillaceus Less.

Gamolepis Less.: 251 (1832). Type species: G. tagetes (L.) DC. (= S. tagetes (L.) Schltr.), lecto. designated by Pfeiffer: 1406 (1874).

Psilothonna (E.Mey. ex DC) E.P.Phillips: (1950), nom. illegit. superfl. pro Gamolepis Less. Gamolepis sect. Psilothonna E.Mey ex DC.: 40 (1838). Type species: P. tagetes (L.) E.P.Phillips $=S$. tagetes (L.) Schltr.

Small, subglabrous annual herbs with flexuose, wiry stems. Leaves alternate, sessile, pinnatisect or bipinnatisect with subsecund linear to filiform lobes, or uppermost leaf simple and filiform, mucronulate, arachnose in axils and on inner face of petiole when young. Capitula pedunculate, solitary on ultimate branches, usually forming lax corymbs; peduncles slender and wiry but widening and fistulose apically, with 1-3 scattered, minute, scale-like bracts. Involucre ecalyculate, subglobse to campanulate-obconic, bracts either free or connate \pm two-thirds into smooth cup. Receptacle convex, epaleate. Ray florets female, bright yellow to orange-yellow, corolla tube cylindrical, sparsely pubescent on outer surface with multicelluar trichomes often concentrated near top of tube, limb oblong, 2-4 times as long as tube, 4(5)-veined, apically 3(4)-toothed. Stigmas linear-oblong, with sterile apical appendage. Disc florets bisexual, evidently fertile but central florets sometimes not developing mature fruits, yellow, corolla narrowly funnel-shaped, 5-lobed, sparsely pubescent or rarely glabrous, lobes suberect, ovate. Anthers ecalcarate and ecaudate, with lanceolate apical appendage. Style terete, branches linear-oblong, margins stigmatic, apices conical with ring of sweeping hairs. Cypselas obovoid or oblong, obscurely 5-angled and 10-ribbed, glabrous or pubescent. Pappus 0 .

5 spp., South African west coast and near interior.

Key to species

1a Involucral bracts free to base, canaliculate (sect. Steirodiscus)

2a Uppermost leaves filiform; involucral bracts and ray florets 8-12; ovaries and cypselas sparsely or densely puberulous; disc florets puberulous on lobes ........ . capillaceus

2b Uppermost leaves pinnatisect or filiform; involucral bracts and ray florets 13-16; ovaries and cypselas glabrous; disc florets glabrous . . . . . . . . . . . linearilobus

1a Involucral bracts connate for most of length into smooth cup (sect. Psilothonna) ...................... 3

3a Leaves mostly $10-20 \mathrm{~mm}$ long with up to 3 pinnae; involucre $3.5-4.5 \mathrm{~mm}$ long; ray florets $4-8$, half as many as involucral lobes; ovaries and cypselas pubescent S. gamolepis

3b Leaves mostly 20-60 $\mathrm{mm}$ long with up to 8 pinnae; involucre 5-8 mm long; ray florets $8-15, \pm$ as many as involucral lobes; ovaries and cypselas glabrous . . . . . . . 4 4

4a Involucre mostly 4-5 mm diam., campanulate; ray floret trichomes compound or lobed, \pm coalescent into fleshy, fimbriate collar at top of tube ........... S. tagetes

$4 \mathrm{~b}$ Involucre mostly 2-3 $\mathrm{mm}$ diam., urceolate and constricted above ovaries when dry; ray floret trichomes simple, \pm scattered at top of tube ......... S. speciosus

\section{Sect. Steirodiscus}

Stems strongly flexuous (zig-zag); involucre cylindrical or subglobose with bracts free to base and canaliculate.

1. Steirodiscus capillaceus (L.f.) Less., Synopsis generum Compositarum: 251 (1832). Cineraria capillacea L.f.: 375 (1782). Psilothonna capillacea (L.f.) E.P.Phillips [as P. capillacea (Less.) E.P.Phillips]: 17 (1950). Type: South Africa, 'Cap. B. Spei' ['in arenosis Swartland' fide Thunberg 1823], Thunberg s.n. UPSTHUNB 19907 (UPS-THUNB , holo.-microfiche!].

Steirodiscus linearilobus sensu Hutch.: 140 (1946), non DC.

Annual herb, 60-200 mm, stem strongly flexuous, corymbosely branched above or rarely below. Leaves alternate, ascending, mostly 15-40(-60) × 8-20 mm, pinnatisect or some leaves bipinnatisect, with up to 8 lobes on each side, lobes alternate or subopposite and subsecund, filiform to linear, 3-10 $\times 0.5 \mathrm{~mm}$, entire or with 1 or 2 lobules, rarely median lobe markedly prolonged, uppermost leaf simple and filiform. Capitula solitary, pedunculate; peduncles $15-60 \mathrm{~mm}$ long, with 2 or 3 minute, scale-like bracts. Involucre subglobose, $4-5 \times 4-5(-10) \mathrm{mm}$, bracts $8-12$, free, convex abaxially and canaliculate adaxially, leathery and three-veined in basal two-thirds, with membranous margins, penicillate. Ray florets as many as involucral bracts and opposite them, yellow; tube cylindrical, $1.5 \mathrm{~mm}$ long, with scattered abaxial trichomes; blade $(5-) 7-10(-15) \times 1.5-3.0$ $\mathrm{mm}$, spreading, recurved apically; ovary ellipsoid, 1.5 
$\mathrm{mm}$ long, antrorsely densely puberulous, style branches partly exserted, $0.5 \mathrm{~mm}$ long. Disc florets fertile, yellow, $4.5 \mathrm{~mm}$ long; tube funnel-shaped, $\pm 2 \mathrm{~mm}$ long; lobes $\pm 1 \mathrm{~mm}$ long, ovate, sparsely puberulous, acute; ovary ellipsoid, $1.5 \mathrm{~mm}$ long, antrorsely densely puberulous, style branches $0.5 \mathrm{~mm}$ long. Cypselas obovoid, \pm 1.5 $\mathrm{mm}$ long, densely antrorsely pubescent. Flowering time: Aug.-Sept. Figure 1.

Distribution and ecology: Steirodiscus capillaceus is the most widely distributed species in the genus, with a curiously scattered range along the West Coast from Hopefield to the foot of Piekenierskloof Pass, in the northern Cedarberg and Bokkeveld Mountains, and further inland on the Klein Roggeveld at the foot of the Komsberg Pass (Figure 2). It favours sandy loam soils, typically in renosterveld shrubland.

Diagnosis and relationships: Steirodiscus capillaceus shares free involucral bracts with $S$. linearilobus, but is distinguished by the puberulous ovaries and cypselas, and by the sparsely puberulous corolla lobes of the disc florets. The uppermost leaves are invariably filiform.
Conservation status: although relatively widespread historically, Steirodiscus capillaceus has not been recorded from the Hopefield-Piketberg-Eendekuil and Bokkeveld localities for over sixty years and appears to be extinct there, likely as a result of agricultural expansion. The only recent records are from the Klein Roggeveld at the foot of the Komsberg Pass, where it is still relatively plentiful.

\section{Additional specimens seen}

NORTHERN CAPE:-3119 (Calvinia): top of Vanrhyn's Pass, (AC), 3 Sept. 1948, R.H. Compton 20878 (NBG); sandy flats, (-AC), 12 Aug. 1961, G.J. Lewis 5898 (NBG). 3220 (Sutherland): Klein Roggeveld, near Farm De Kom, (-DA), 15 Sept., 2004, D.A. Snijman 1951 (NBG); $9.5 \mathrm{~km} \mathrm{~S}$ of top of Komsberg Pass, 4 055' [1 $230 \mathrm{~m}$ ], (-DA), shale flats in valley bottom, 9 Sept. 2006, P. Goldblatt \& L.J. Porter 12805 (MO, NBG); Klein Roggeveld, near rest stop above Farm Fortuin, (-DA), 18 Sept. 2011, P. Goldblatt \& J.C. Manning 13675 (MO, NBG); foot of Komsberg Pass, (-DA), 10 Sept. 2012, J. Manning 3376 (NBG); Farm De Plaat, N of homestead, $3750^{\prime}$ [1 $130 \mathrm{~m}$ ], (-DC), Karoo vegetation on sandy loam, 6 Sept. 1988, A. Fellingham 1393 (NBG, PRE).

WESTERN CAPE.-3218 (Clanwilliam): Piquenierskloof [Piekenierskloof], (-DB), 6 Aug. 1897, R. Schlechter 10757 (BOL, PRE); Piketberg, Witwater, (-DC), 4 Oct. 1895, H. Bolus 8495

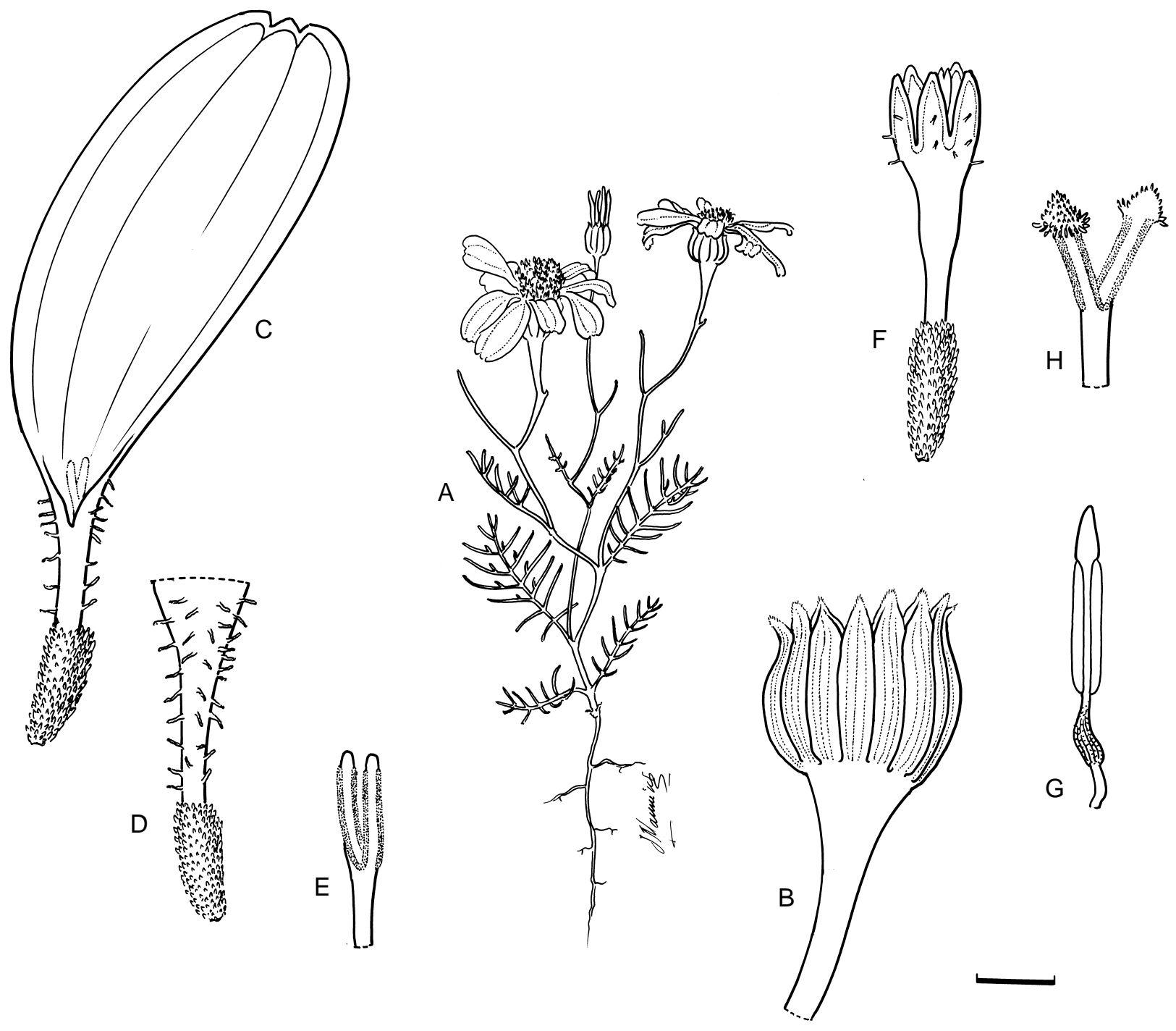

FIGURE 1.-Steirodicus capillaceus, Manning 3376. A, plant; B, involucre; C, ray floret; D, ray floret detail of abaxial side of tube; E, ray floret stigma; F, disc floret; G, disc floret anther; H, disc floret stigma. Scale bar: A, 10 mm; B, 2mm; C, D, F, 1 mm; E, G, H, 0.5 mm. Artist: J. Manning. 


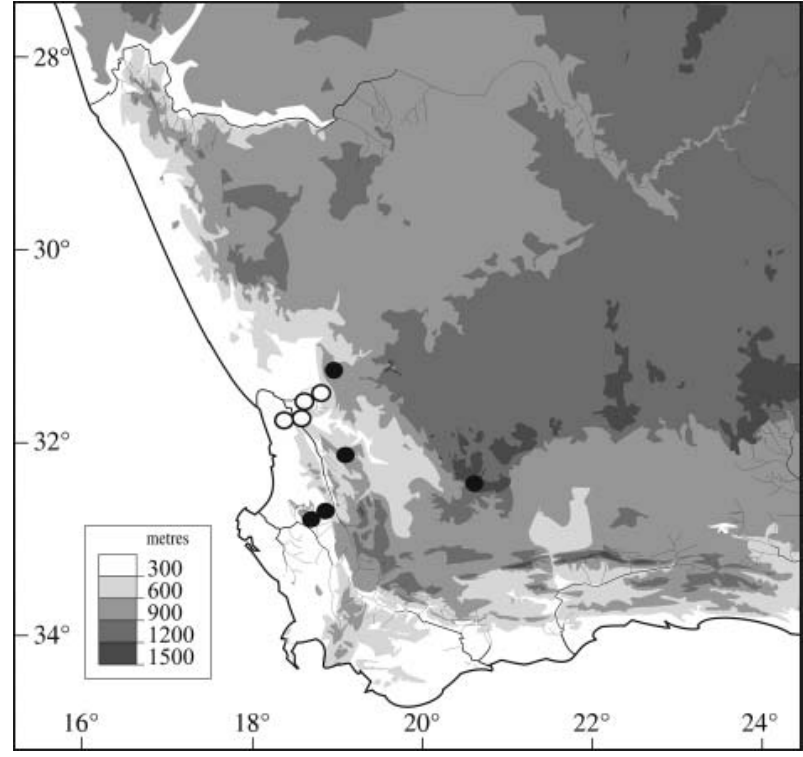

FIGURE 2.-Distribution of Steirodiscus capillaceus, $\bullet$; and S. linearilobus, $\circ$.

(NBG, PRE). 3219 (Wuppertal): Koudeberg, (-AA), 28 Aug. 1896, $R$ Schlechter 8721 (BOL, PRE); Bidouw, (-AA), 7 Sept. 1953, R.H. Compton 24232 (NBG); Wuppertal, (-AC), 20 Aug. 1959, W.F Barker 8992 (NBG); gate at entrance to Wuppertal property, (-AC), 8 Sept. 1974, P.Goldblatt 2530 (MO, NBG); Braakfontein [Citrusdal], (-?CA), 11 Sept. 1894, R. Schlechter 5282 (PRE). 3318 (Cape Town): near Hopefield, (-AB), Sept. 1905, H. Bolus 12706 (BOL).

2. Steirodiscus linearilobus DC., Prodromus systematis naturalis regni vegetabilis 6: 74 (1838 '1837'). Type: South Africa, Olifantsrivier, Knakarberg [Knakkiesberg], foot of hills, July 1839, Drege s.n. (G-DC, holo.-microfiche!; E, HAL, HBG, K, iso.-ALUKA images!).

Steirodiscus schlechteri Bolus: 217 (1899), syn. nov. Psilothonna schlechteri (Bolus) E.P.Phillips: 17 (1950). Type: South Africa, [Western Cape], Vanrhynsdorp Dist., Windhoek [Farm], 31 July 1896, R. Schlechter 8358 (BOL, holo.!; $\mathrm{S}$, iso.).

Annual herb, 60-150 mm, stem strongly flexuous, corymbosely branched above. Leaves alternate, ascending, mostly $20-60 \times 15-20(-35) \mathrm{mm}$, pinnatisect or bipinnatisect, with up to 10 lobes on each side, lobes alternate or subopposite and subsecund, filiform to linear, 3-15 $\times 0.5 \mathrm{~mm}$, entire or with 1 or 2 lobules, uppermost leaves usually pinnatisect, sometimes simple and filiform. Capitula solitary, pedunculate; peduncles 20-50 $\mathrm{mm}$ long, with 2 or 3 minute, scale-like bracts. Involucre cylindrical to subglobose, 4-5 × 4-5 mm, bracts $13-16$, free, convex abaxially and canaliculate adaxially, leathery and three-veined in basal two-thirds, with membranous margins, penicillate. Ray florets fewer than involucral bracts, 7-10, yellow; tube cylindrical, $2.5 \mathrm{~mm}$ long, with abaxial trichomes near top; blade 7-10 × 1.5-2.0 $\mathrm{mm}$, spreading, recurved apically; ovary terete with slightly thickened distal collar, $1.5 \mathrm{~mm}$ long, glabrous, style branches exserted, $1 \mathrm{~mm}$ long. Disc florets bisexual, yellow, $5 \mathrm{~mm}$ long; tube funnel-shaped, $\pm 3 \mathrm{~mm}$ long; lobes $\pm 1 \mathrm{~mm}$ long, ovate, acute; ovary terete, 1.5 $\mathrm{mm}$ long, glabrous, style branches $1 \mathrm{~mm}$ long. Cypselas unknown. Flowering time: Aug. (Sept.). Figure 3.
Distribution and ecology: only rarely collected, Steirodiscus linearilobus is a local endemic of the lower reaches of the Olifants River and adjacent flats south and east of Vanrhynsdorp, recorded from the Knakkiesberg west of Klawer, northeastwards to the foot of the Kobee Mountains (Figure 2). The species occurs on sandy flats in open shrubland, including Klawer Sandy Shrubland (Mucina \& Rutherford 2006).

Diagnosis and relationships: Steirodiscus linearilobus is distinguished from $S$. capillaceus by its glabrous ovaries and cypselas, and by its glabrous disc florets. The ray florets are slightly fewer than the involucral bracts, which number $13-16$ vs. 8-12 in S. linearilobus, and the uppermost leaves are either simple or pinnatisect, but invariably simple in S. capillaceus.

Steirodiscus linearilobus was described from a collection made by Drège at the base of the Knakkiesberg, an inselberg west of Klawer (Candolle 1838) but the name was inexplicably overlooked by Phillips (1950) in his review of the genus (as Psilothonna). A later collection from just east of Klawer formed the basis for Steirodiscus schlechteri (Bolus 1899), separated from S. linearilobus essentially by its glabrous ovaries. The vestiture of the ovaries in S. linearilobus is not mentioned in the protologue and its identity has remained uncertain until now. It is only through the kindness of Mark Newman at the Royal Botanic Garden, Edinburgh, who dissected the Edinburgh isotype and confirmed that the ovaries of Drège's collection are glabrous (Newman pers. com.), that we are able to establish firmly that the two names are conspecific. Bolus (1899) distinguished S. schlechteri from $S$. linearilobus (and $S$. capillaceus) by its stouter habit, smaller leaves, larger heads, and glabrous achenes, but this is evidently just a general diagnosis of the species rather than an implication that the ovaries in $S$. linearilobus are pubescent. This implied pubescence of the ovaries in S. linearilobus led Hutchinson (1946) to misapply the name to his collection of $S$. capillaceus from the Klein Roggeveld.

Conservation status: Steirodiscus linearilobus is a local endemic known historically from just four localities in close proximity to one another. The only recent collection is from the verge of the N7 motorway south of Klawer.

\section{Additional specimens seen}

WESTERN CAPE.-3118 (Vanrhynsdorp): Urionskraal, (-DB), 4 Sept. 1955, W.F. Barker 8569 (NBG); sandy flats near foot of Tigerberg [Tierberg], 4 Sept. 1955, G.J. Lewis 4665 (SAM); Klawer, (-DC), Oct. 1917, Roberts \& Adendorff 17685 (PRE); Van Rhynsdorp Road near Klawer, (-DC), Aug. 1932, M. Lavis 20259 (BOL); $\pm 5 \mathrm{~km} \mathrm{~S}$ of Klawer, cutting on N7, (-DC), 24 Aug. 2012, J. Manning 3367 (NBG).

Uncertain locality: Namaqualand, Aug. 1931, J.W. Mathews s.n. (BOL).

sect. Psilothonna (E.Mey ex DC.) J.C.Manning \& Goldblatt, comb. nov. Gamolepis sect. Psilothonna E.Mey ex DC.: 40 (1838). Type species: S. tagetes (L.) Schltr.

Stems weakly or more strongly flexuous; involucre campanulate or obconic with bracts connate \pm two-thirds in a smooth cup. 


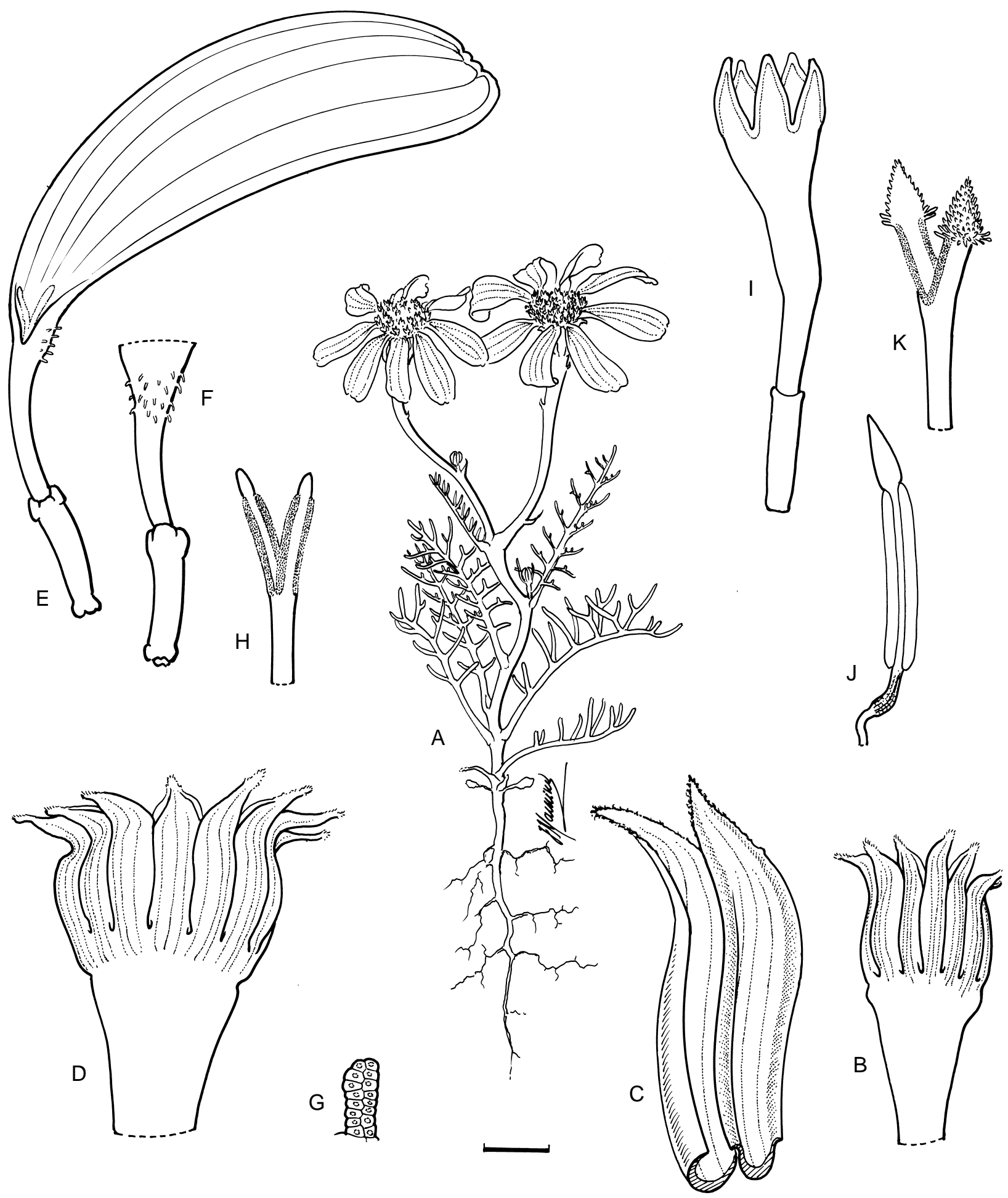

FIGURE 3.-Steirodicus linearilobus, Manning 3367. A, plant; B, involucre; C, detached involucral bracts, abaxial view; D, fruiting involucre; E, ray floret; F, ray floret detail of abaxial side of tube; G, ray floret trichome (much enlarged); H, ray floret stigma; I, disc floret; J, disc floret anther; K, disc floret stigma. Scale bar: A, $10 \mathrm{~mm}$; B, D, 2mm; C, E, F, I, $1 \mathrm{~mm}$; H, J, K, $0.5 \mathrm{~mm}$. Artist: J. Manning.

3. Steirodiscus tagetes (L.) Schltr. in Botanische Jahrbücher fur Systematik, Pflanzengeschichte und Pflanzengeographie: 216 (1899), in obs. Othonna tagetes L.: 1234 (1758). Gamolepis annua Less.: 251 (1832), nom. illegit. superfl. Gamolepis tagetes (L.) DC.: 40 (1838 '1837'). Psilothonna tagetes (L.) E.P.Phillips: 17 (1950). Type: South Africa, without locality or collector, Herb. Linn. 1038.1 [LINN-ALUKA image!, lecto., designated by Nordenstam in Jarvis: 716 (2007].
Annual herb, (50-)100-200 mm, stem flexuous, corymbosely branched above. Leaves alternate, ascending, mostly 30-60 × 15-20 mm, pinnatisect or some leaves rarely bipinnatisect, with up to 8 lobes on each side, lobes alternate or subopposite and subsecund, filiform to oblong, 5-12 $\times 0.5-1.0(-1.5) \mathrm{mm}$, entire or with 1 or 2 lobules, uppermost leaves sometimes simple and linear-filiform. Capitula solitary, pedunculate; peduncles 10-60 mm long, with 2 or 3 minute, scale-like bracts. 
Involucre campanulate, 5-8 $\times 4-5(-6) \mathrm{mm}$, bracts (8-)10-13(-15), connate for two-thirds their length, free parts lanceolate, with narrow membranous margins, penicillate. Ray florets as many as bracts and opposite them, $8-15$, yellow or rarely pale orange; tube narrowly cylindrical, $\pm 3.5 \mathrm{~mm}$ long, with abaxial trichomes in transverse band at top of tube, trichomes fleshy and coalescent or palmate and forming distinct fimbriate collar at junction between tube and blade; blade 8-10 $\times 3-4 \mathrm{~mm}$, spreading, recurved apically; ovary terete, $2.5 \mathrm{~mm}$ long, glabrous, longitudinally colliculate, style branches partly or fully exserted, $\pm 1 \mathrm{~mm}$ long. Disc florets bisexual, yellow, 6-7 mm long; tube narrowly funnel-shaped, \pm $4.5 \mathrm{~mm}$ long, sparsely pubescent in distal half; lobes \pm $1 \mathrm{~mm}$ long, ovate, acute; ovary terete, $2 \mathrm{~mm}$ long, glabrous, longitudinally colliculate, style branches $\pm 1 \mathrm{~mm}$ long. Cypselas obovoid-prismatic, $\pm 2.5 \mathrm{~mm}$ long, glabrous, longitudinally colliculate, obscurely 5 -angled and 10-ribbed. Flowering time: Sept.-Oct. Figure 4.

Distribution and ecology: Steirodiscus tagetes is relatively widely distributed along the West Coast of Western Cape, from St Helena Bay to False Bay (Figure 5). There are historical records from the Cape Peninsula but the species is probably now extinct there. It occurs on sand dunes near the coast, typically in lightly disturbed situations in strandveld vegetation, especially Cape Flats Dune Strandveld, where it may be locally abundant.

Diagnosis and relationships: the most common member of sect. Psilothonna, Steirodiscus tagetes is distinguished by the characteristic compound trichomes on the ray florets. These palmate structures (Figure 4E) form a fleshy, collar-like fringe around the top of the corolla tube at the base of the limb (Figure 4C, D), and are readily visible with a hand lens. The capitula are typically larger than in S. gamolepis and S. speciosus, with a campanulate involucre $4-5 \mathrm{~mm}$ diam. It is superficially very similar to $S$. speciosus, but in this species the trichomes on the ray florets are not coalescent into compound structures and the involucre is generally smaller, 2-3 mm diam. The flowers in both species are typically bright yellow but may also be tinged orange. The species is variable in flower size with the largest and most attractive forms occurring west of Atlantis.

Conservation status: Once relatively widely recorded along the West Coast, Steirodiscus tagetes is now extinct from the Cape Peninsula and probably also around Langebaan as a result of the extensive urbanisation there. The only recent collections are those from Macassar and along the West Coast west of Atlantis.

\section{Additional specimens seen}

WESTERN CAPE $-\mathbf{3 2 1 8}$ (Clanwilliam): $\pm 5 \mathrm{~km} \mathrm{~S}$ of St Helena Fransvlei, 120 m, (-CC), 3 Sept. 2008, N. Helme 5643 (NBG); Berg River, (-CD), 21 Sept. 1940, R.H. Compton 9472 (NBG); Berg River Station, (-CD), in sand, 1 Oct. 1943, R.H. Compton 15105 (NBG). 3318 (Cape Town): Saldanha Bay, hillside, (-AA), 27 Sept. 1930, E.E. Galpin 11500 (PRE); hills NE of Langebaan, (-AA), Oct. 1933, N.S. Pillans 7005 (BOL); Geelbek road, (-AA), 28 Sept. 1953, W.F. Barker 8159 (NBG); near Langebaan, (-AA), 2 Oct. 1970, M.R. Levyns 11725 (BOL); near Hopefield, (-AB), 13 Sept. 1894, R. Schlechter 5322 (SAM); sand dunes on W coast opposite turnoff to Atlantis, (-CA), 11 Sept. 2004, P. Goldblatt \& L.J. Porter 12395 (MO, NBG); R307 opposite Atlantis, (-CB), 29 Sept. 2012, J. Manning 3377 (NBG); W coast N of Atlantis turnoff, (-CB), 26 Sept. 1998, P. Goldblatt \& J. Manning 11028 (MO, NBG); Melkbosch Strand, (-CB), 16 Oct. 1947,
Schrieber s.n. NBG24181 (NBG); sandy places, Paarden Eiland, Nov. without year, Zeyher s.n . (SAM); Cape Flats, Stikland, 62 m, (-DC), 30 Aug. 1979, C. Boucher 4501 (NBG); Cape Flats, (-DC), 16 Sept. 1944, R.H. Compton 15975 (NBG); between Brackenfell and Kraaifontein along road to Paarl, (-DC), 17 Sept. 1975, E. Esterhuysen 33975 (BOL); Cape Flats Nature Reserve, (-DC), 27 Oct. 1978, A.B Low 738 (NBG). 3418 (Simonstown): Hout Bay, (-AB), 4 Sept. 1941, R.H. Compton 112289 (NBG); 3 Sept. 1950, A.J. Middelmost 1576 (NBG); Klipfontein Road, (-BA), sand dunes, 30 Aug. 1931, M.R. Levyns 3172 (BOL); coastal dunes between Eerste River and Swartklip, (-BA), 1 Oct. 1939, N.S. Pillans 9207 (BOL); Durban Road Station, (-CD), Sept. 1877, H. Bolus 3778 (BOL, SAM); near Retreat Station, (-AB), Sept. 1892, H. Bolus 7242 (BOL, PRE); Strandfontein, (-BA), 18 Sept. 1942, R.H. Compton 13697 (NBG); Somerset Strand, (-BB), 2 Oct. 1921, G.C. Nel 1282 (PRE); Macassar, Somchem, 20 m, (-BB), 28 Sept. 1995, A.B. Louw 2473 (NBG).

Without precise locality: 'prope Piketberg', Oct. 1892, H. Bolus 13575 (PRE); 'prope Darling', Sept. 1905, H. Bolus 12734 (PRE).

Uncertain collections: Groenekoof [Mamre], without date, Zeyher s.n. pp. (SAM); 'Prom. bon. Spei, Driefontein', Nov. without year, Zeyher 828 pp. (SAM) [These two collections by Zeyher include plants of both $S$. tagetes and $S$. speciosus, but as these are hopelessly muddled between the various duplicates it is unclear whether they were growing together or mixed up later].

4. Steirodiscus speciosus (Pillans) B.Nord. in Opera Botanica 20: 31 (1968), in obs. Gamolepis speciosa Pillans: 50 (1931). Psilothonna speciosa (Pillans) E.P.Phillips: 17 (1950). Type: South Africa, [Western Cape], between Darling and the coast, exhibited at Darling Show, Sept. 1929, collector unknown Pillans sub BOL18965 (BOL, holo.!; K, iso.-ALUKA image!).

Annual herb, 80-300 mm, stem flexuous, corymbosely branched above. Leaves alternate, ascending, mostly 30-40 × 15-20 mm, pinnatisect or some leaves rarely obscurely bipinnatisect, with up to 7 lobes on each side, lobes alternate or subopposite and subsecund, filiform, 3-12 $\times 0.5 \mathrm{~mm}$, entire or with 1 or 2 lobules, uppermost leaf sometimes simple and filiform. Capitula solitary, pedunculate; peduncles $20-40 \mathrm{~mm}$ long, with 1-3 minute, scale-like bracts. Involucre campanulate when fresh but drying urceolate with marked constriction above ovaries, 5-6 × 2-4 mm, bracts 11-15(-18), connate for two thirds their length, free parts lanceolate, with narrow membranous margins, penicillate. Ray florets \pm as many as bracts and opposite them, 11-18, yellow or rarely pale orange; tube narrowly cylindrical, 2.0-3.5 mm long, with scattered abaxial trichomes at top of tube; blade 7-10 $\times 3-4 \mathrm{~mm}$, spreading, recurved apically; ovary terete, $2.5 \mathrm{~mm}$ long, glabrous, longitudinally colliculate, style branches partly or fully exserted, $\pm 1 \mathrm{~mm}$ long. Disc florets bisexual, yellow, 4-5 mm long; tube narrowly funnel-shaped, 3-4 mm long, sparsely pubescent in distal half; lobes $\pm 1 \mathrm{~mm}$ long, ovate, acute; ovary terete, $2.5 \mathrm{~mm}$ long, glabrous, longitudinally colliculate, style branches $\pm 1 \mathrm{~mm}$ long. Cypselas obovoid-prismatic, $\pm 2.5 \mathrm{~mm}$ long, glabrous, longitudinally colliculate. Flowering time: Sept.-Oct. Figure 6.

Distribution and ecology: a highly local endemic of the West Coast between Darling and Atlantis (Figure 5), Steirodiscus speciosus is very poorly known. Described from plants collected between Darling and the coast 


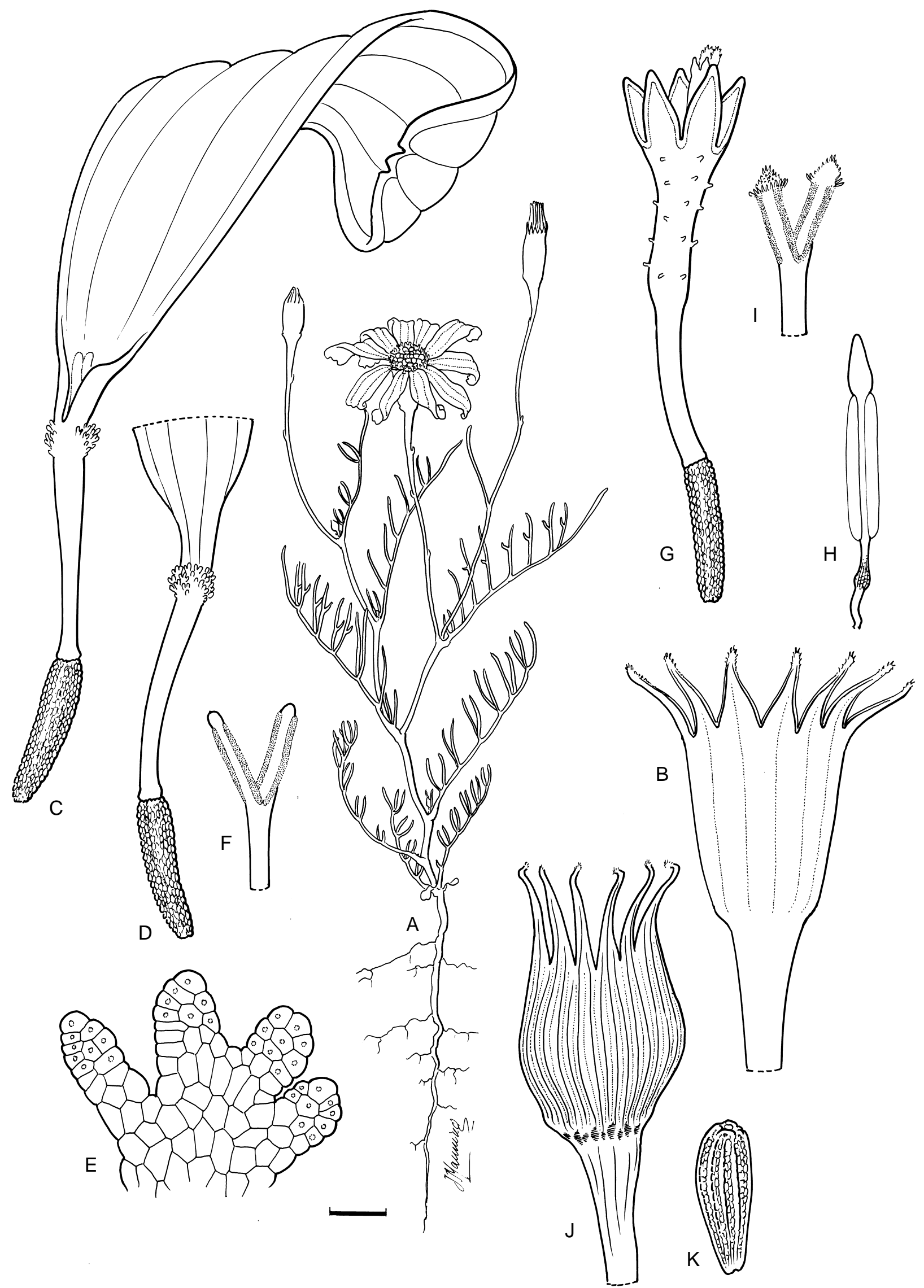

FIGURE 4.-Steirodicus tagetes, Manning 3377. A, plant; B, involucre; C, ray floret; D, ray floret detail of abaxial side of tube; E, ray floret trichome (much enlarged); F, ray floret stigma; G, disc floret; H, disc floret anther; I, disc floret stigma; J, ray cypsela; K, disc cypsela. Scale bar: A, $10 \mathrm{~mm}$; B, 2mm; C, D, G, J, K, 1 mm; F, H, I, 0.5 mm. Artist: J. Manning. 


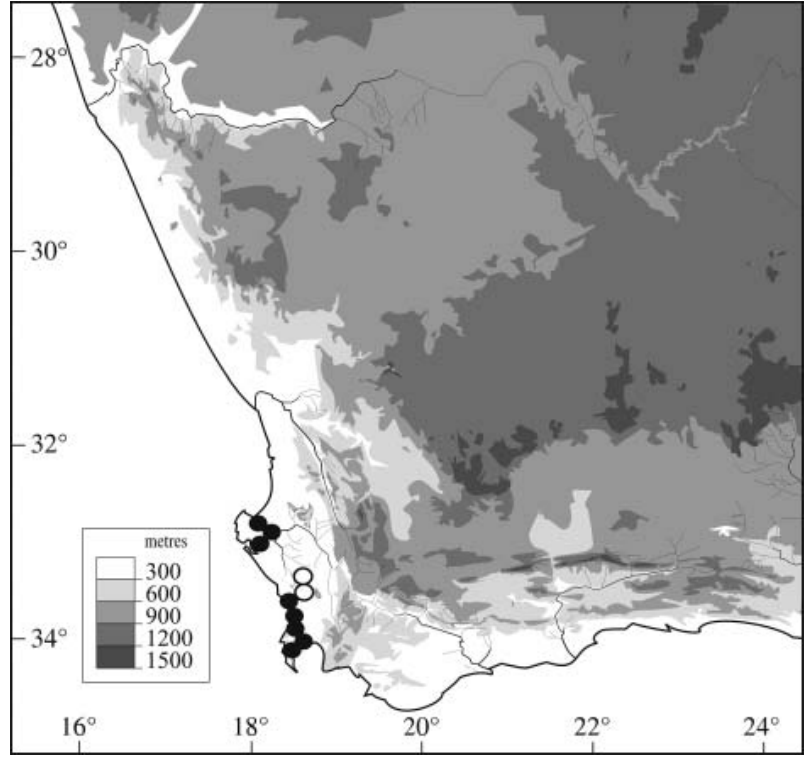

FIGURE 5.-Distribution of Steirodiscus tagetes, $\bullet$; and S. speciosus, ○.

and exhibited at the Darling Show in September 1929, the only recent collections of the species are from near Atlantis, where we have found it in deep sandy soils in sand plain fynbos, specifically Atlantis Sand Fynbos (Mucina \& Rutherford 2006). The records for S. speciosus all fall within the distribution of this vegetation type and the species thus appears to be restricted to it. Germination in $S$. speciosus is evidently stimulated by light disturbance as we first encountered the species after a fire the previous summer and later along the roadside but have never seen it in mature vegetation.

Diagnosis and relationships: Steirodiscus speciosus is very similar to $S$. tagetes and was diagnosed against it by Pillans (1931) (as G. annua), and as having larger $( \pm 18 \times 3.5-4.0 \mathrm{~mm})$, more numerous $(14-23)$ orange rays lacking a distinct annulus of papillae around the mouth of the tube and with more strongly exserted styles. Most of these characters do not hold, even in the type of $S$. speciosus, which has up to 15 rays that are no larger than are found in most populations of $S$. tagetes and also does not differ in the stylar characters. Although the specific status of the taxon was questioned in 1933 by R.A. Dyer (letter on K isotype), Phillips (1950) accepted the species in his synopsis of the genus (as Psilothonna), but keyed it against $S$. tagetes solely on the absence (vs. presence) of 'glands' at the base of the rays. Both taxa, like all species in the genus, have multicellular trichomes ('glands') at the top of the ray corolla tube on the abaxial (outer) side and the critical difference between them is in the nature of the trichomes themselves. In $S$. tagetes the trichomes coalesce into compound, palmate structures (Figure 4E) that form a fimbriate collar around the corolla tube (Figure 4C, D) whereas in $S$. speciosus the individual trichomes remain discrete (Figure 6C, D). S. speciosus is also distinguished by its smaller involucre, $2-4 \mathrm{~mm}$ diam., which constricts markedly above the ovaries as it dries, giving it a characteristic urceolate shape in herbarium specimens (Figure 6B). This is not evident in fresh material, at which time the distinction between the two species is more cryptic, requiring careful examination of the ray floret vestiture with a hand lens. Ecologically $S$. speciosus appears to favour sand plain fynbos (this remains to be confirmed for additional populations) whereas $S$. tagetes is definitely restricted to strandveld vegetation along the coast.

Conservation status: Steirodiscus speciosus is a highly local endemic with just a single recent collection near Atlantis, where it is under immediate threat from urbanisation.

\section{Additional specimens seen}

WESTERN CAPE.-3318 (Cape Town): Darling, (-AC), 16 Oct. 1942, Mrs W.M. Duckitt NBG24186 (NBG); near Darling, (-AC), Sept. 1946, T.P. Stokoe SAM59958 (SAM ); 11 Sept. 1950, M. Johns NBG 24185 (NBG); Mamre Road, (-BC), sand, 2 Oct. 1931, M.R. Levyns 3269 (BOL); sandy flats 2 miles [3 km] S of Mamre, $(-\mathrm{CB})$, 1 Sept. 1940, N.S. Pillans 9255 (BOL). 3320 (Cape Town): between Melkbos and Mamre, (-CB), 1932, L. Bolus s.n. PRE43910 (PRE); 16 $\mathrm{km}$ along Mamre road from turn-off on Melkboschstrand road, $(-\mathrm{CB})$, 23 Sept. 1974, Nordenstam \& Lundgren 1986 (S); sandy flats near Atlantis, S of Mamre, (-CB), bright orange flowers, 27 Sept. 1995, P. Goldblatt \& J. Manning 10334 (MO, NBG); $500 \mathrm{~m} \mathrm{~S}$ of MamreAtlantis T-junction, (-CB), 10 Oct. 2012, J.Manning \& Goldblatt 3383 (NBG).

Uncertain collections: Groenekoof [Mamre], without date, Zeyher s.n. pp. (SAM); Rietvley [Rietvlei], without date, Zeyher 1679 (BOL, NBG); 'Prom. bon. Spei, Driefontein', Nov. without year, Zeyher 828 pp. (BOL, NBG, SAM). [These three collections by Zeyher include plants of both $S$. tagetes and $S$. speciosus but as these are hopelessly muddled between the various duplicates, it is unclear whether they were growing together or mixed up later].

5. Steirodiscus gamolepis Bolus in Schltr. in Botanische Jahrbücher fur Systematik, Pflanzengeschichte und Pflanzengeographie 27: 216 (1899). Psilothonna gamolepis (Bolus) E.P.Phillips: 17 (1950). Type: South Africa, [Western Cape], Ceres Road, 11 Sept. 1896, R. Schlechter 8974 (BOL, lecto.!, designated here; BR, E, HBG, K, M, P, PRE, S, isolecto.-ALUKA images!). [Syntype: South Africa, [Western Cape], Tulbagh Kloof, 30 Sept. 1892, H. Bolus 8605 (BOL!, NBG!, NH, PRE, syn.]. [The Schlechter collection is selected as lectotype as being better represented in herbaria internationally.]

Annual herb, 60-130 mm, stem flexuous, simple or sparsely corymbosely branched above. Leaves alternate, ascending, mostly $10-20 \times 5-10 \mathrm{~mm}$, trisect or pinnatisect, with 1-3 lobes on each side, lobes alternate or opposite and subsecund, filiform, $1-5 \times 0.5 \mathrm{~mm}$, uppermost leaves simple and filiform. Capitula solitary, conspicuously pedunculate; peduncles $30-60 \mathrm{~mm}$ long, with 1 or 2 minute, scale-like bracts. Involucre narrowly campanulate or obconic, $3.5-4.5 \times 1.5-3.0 \mathrm{~mm}$, bracts 10-14, connate for two thirds their length, free parts lanceolate, with narrow membranous margins, penicillate. Ray florets \pm half as many as bracts, 4-8, yellow; tube narrowly cylindrical, $2 \mathrm{~mm}$ long, with scattered abaxial trichomes at top of tube extending onto base of blade; blade 6-8 6 2-3 mm, spreading, recurved apically; ovary terete, $2 \mathrm{~mm}$ long, antrorsely pubescent in basal two thirds, style branches exserted, $\pm 0.75 \mathrm{~mm}$ long. Disc florets bisexual, yellow, $3 \mathrm{~mm}$ long; tube funnelshaped, $2 \mathrm{~mm}$ long, glabrous; lobes $\pm 1 \mathrm{~mm}$ long, ovate, 


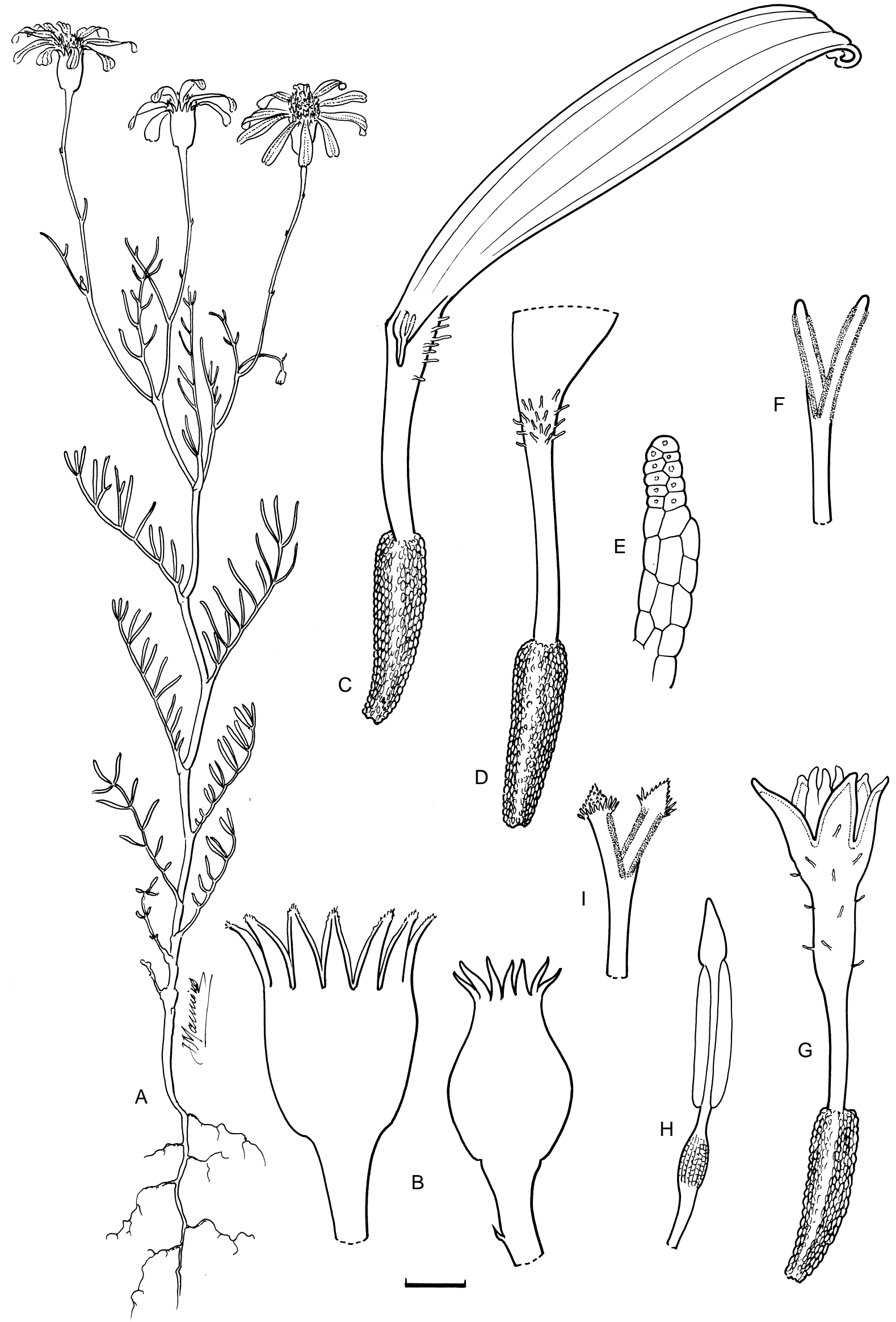

FIGURE 6.-Steirodicus speciosus, Manning \& Goldblatt 3383. A, plant; B, involucre, fresh (left) and dried (right); C, ray floret; D, ray floret detail of abaxial side of tube; E, ray floret trichome (much enlarged); F, ray floret stigma; G, disc floret; H, disc floret anther; I, disc floret stigma. Scale bar: A, $10 \mathrm{~mm}$; B, 2mm; C, D, G, $1 \mathrm{~mm} ; \mathrm{F}, \mathrm{H}, \mathrm{I}, 0.5 \mathrm{~mm}$. Artist: J. Manning. 
acute; ovary terete, $2 \mathrm{~mm}$ long, antrorsely pubescent in basal two thirds, style branches $0.5 \mathrm{~mm}$ long. Cypselas flask-shaped (ray) or terete (disc), $\pm 2 \mathrm{~mm}$ long, antrorsely pubescent in basal two thirds. Flowering time: Aug.-Sept. Figure 7.

Distribution and ecology: Steirodiscus gamolepis is restricted to the flats at the foot of the Elandskloof Mountains near Tulbagh (Figure 8) and remained very poorly known until recent collections established its occurrence on Elandsberg Nature Reserve, where it is now best known. The type from Ceres Road appears to come from the Tulbagh Valley itself, but other records are from the western side of the mountains between Gouda and Hermon. At Elandsberg Nature Reserve, S. gamolepis is locally abundant on seasonally wet gravelly flats in alluvium fynbos shrubland, and available data suggests that the species is endemic to Swartland Alluvium fynbos and possibly also Breede Alluvium Fynbos (Mucina \& Rutherford 2006).

Diagnosis and relationships: The smallest species in the genus, Steirodiscus gamolepis is distinctive in its short, few-lobed leaves and diminutive, markedly pedunculate capitula with the peduncle grading into the narrowly campanulate or obconic involucre. The rays are relatively few, up to half as many as the involucral lobes, and the ovaries and cypselas are pubescent in the basal two thirds but glabrous above. The corollas of the disc florets are glabrous and unique in the genus in the

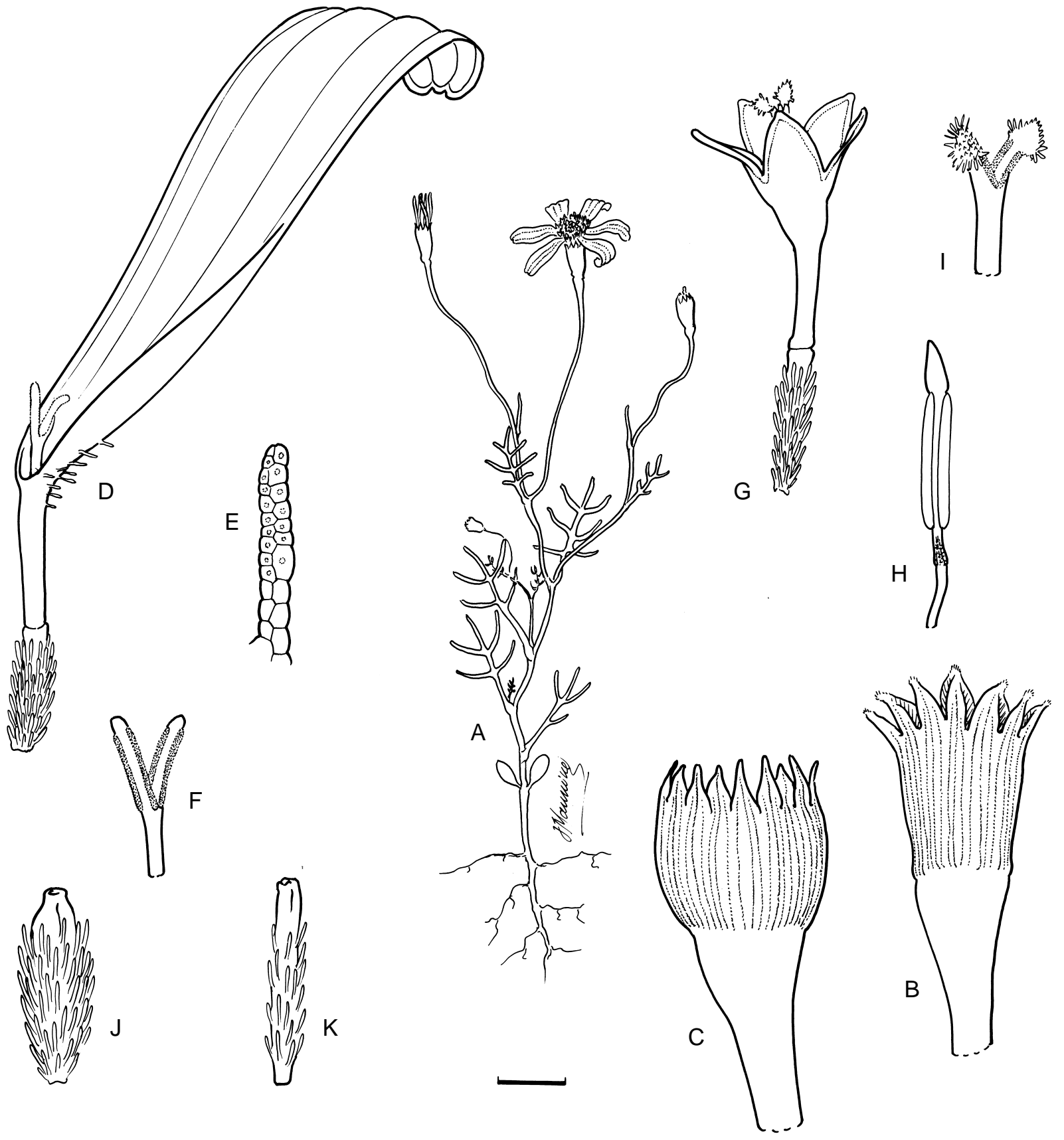

FIGURE 7.- Steirodicus gamolepis, Manning 3366A. A, plant; B, involucre; C, fruiting involucre; D, ray floret; E, ray floret trichome (much enlarged); F, ray floret stigma; G, disc floret; H, disc floret anther; I, disc floret stigma; J, ray cypsela; K, disc cypsela. Scale bar: A, 10 mm; B, C, 2mm; D, G, J, K, $1 \mathrm{~mm} ; \mathrm{F}, \mathrm{H}, \mathrm{I}, 0.5 \mathrm{~mm}$. Artist: J. Manning. 


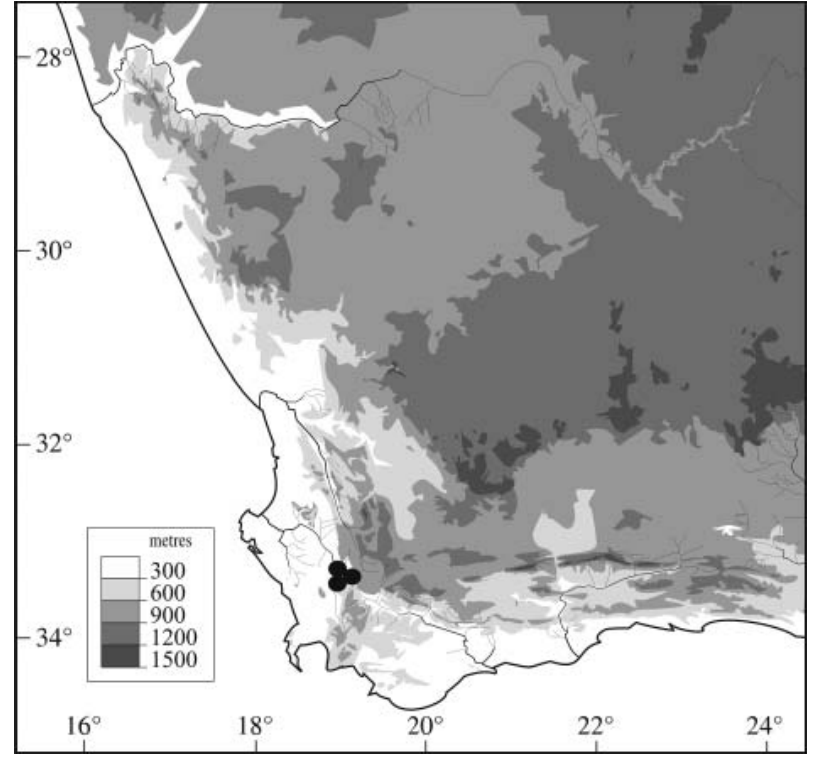

FIGURE 8.-Distribution of Steirodiscus gamolepis,

short upper expanded portion of the perianth tube, much shorter than both the cylindrical lower portion and the lobes. Other members of sect. Psilothonna are larger in all respects, with less conspicuous peduncles that are sharply differentiated from the involucre, \pm as many rays as involucral lobes, disc florets that are sparsely puberulous on the corolla, with the upper expanded portion \pm as long as the lobes and the lower portion, and glabrous ovaries and cypselas. The peduncles in S. gamolepis are unusually tough and wiry. The seasonally inundated habitat is unique in the genus, other species preferring drier, mostly sandy flats.

Conservation status: Steirodiscus gamolepis is a highly local endemic known to persist only at Elandsberg Nature reserve, where it is still relatively plentiful.

\section{Additional specimens seen}

WESTERN CAPE.-3319 (Worcester): flats near Piquetberg Station, (-AA), Oct. 1892, F. Guthrie 2624b (NBG); Elandsberg Farm and Nature Reserve, (-AC), 24 Aug. 2009, L. Husted 780 (NBG); BoHermon, Elandsberg Nature Reserve, (-AC), 15 Oct. 2011 [fruiting], Manning 3359 (NBG); 15 Oct. 2011, J. Manning 3359 (NBG); 10 Aug. 2012, J. Manning 3366A (NBG).

\section{ACKNOWLEDGEMENTS}

We are grateful to Elizabeth Parker and Stephen Boatwright for assistance in the field, and to Bertil Nor- denstam for valuable comments and additional records from S. The electronic maps were prepared by Michelle Smith. Material was collected under permits from the conservation authorities of Western and Northern Cape provinces.

\section{REFERENCES}

DE CANDOLLE, A.P. 1838 ['1837']. Prodromus systematis naturalis regni vegetabilis 6 . Treuttel \& Würtz, Paris.

GOLDBLATT, P. \& MANNING, J.C. 2000. Cape plants: a conspectus of the Cape flora of South Africa. Strelitzia 9. National Botanical Institute, Cape Town \& Missouri Botanical Garden, St Louis.

HERMAN, P.P.J., RETIEF, E., KOEKEMOER, M. \& WELMAN, W.G. 2000. Asteraceae. In O.A. Leistner (ed.), Seed plants of southern Africa. Strelitzia 10: 101-170. National Botanical Institute, Pretoria.

HOLMGREN, P.K., HOLMGREN, N.H. \& BARNETT, L.C. 1990. Index Herbariorum. Part. 1: The Herbaria of the World. New York Botanical Garden, New York.

HUTCHINSON, J. 1946. A botanist in southern Africa. Gawthorn, London.

JARVIS, C.E. 2007. Order out of chaos: Linnaean plant names and their types. Linnean Society of London in Association with the Natural History Museum, London.

JEFFREY, C. 1992. The tribe Senecioneae (Compositae) in the Mascarene Islands with an annotated world checklist of the genera of the tribe. Kew Bulletin 47: 49-109.

LESSING, C.F. 1832. Synopsis generum Compositarum. Duncker \& Humblot, Berlin.

LINNAEUS, C. 1758. Systema naturae, edn 10. Stockholm.

LINNAEUS, C. fil. 1782 ['1781']. Supplementarum plantarum. Braunschweig.

MUCINA, L. \& RUTHERFORD, M.C. (eds) 2006. The vegetation of South Africa, Lesotho and Swaziland. Strelitzia 19. South African National Biodiversity Institute, Pretoria.

NORDENSTAM, B. 1968. The genus Europs Part 1. Taxonomy. Opera Botanica 20: 1-409.

NORDENSTAM, B., PELSER, P.B., KADEREIT, J.W. \& WATSON, L. 2009. Senecioneae. In V.A. Funk, A. Susanna, T.F. Stuessy \& R.J. Bayer (eds), Systematics, evolution, and biogeography of Compositae: 503-525. International Association for Plant Taxonomy, Vienna.

PELSER, P., KENNEDY, A.H., TEPE, E.J., SHIDLER, J.B., NORDENSTAM, B., KADEREIT, J.W. \& WATSON, L.E. 2010. Patterns and causes of incongruence between plastid and nuclear Senecioneae (Asteraceae) phylogenies. American Journal of Botany 97: 856-873.

PFEIFFER, L. 1874. Nomenclator botanicus, 1(2). Cassel.

PHILLIPS, E.P. 1950. Descriptions and changes of name. Journal of South African Botany 16: 15-17.

PILLANS, N.S. 1931. Gamolepis speciosa. Journal of Botany 69: 50.

RAIMONDO, D., VON STADEN, L., FODEN, W., VICTOR, J.E., HELME, N.A., TURNER, R.C., KAMUNDI, D.A. \& MANYAMA, P.A. (eds). 2009. Red List of South African Plants. Strelitzia 25. South African National Biodiversity Institute, Pretoria.

SCHLECHTER, R. 1899. Plantae Schlechterianae novae vel minus cognitae describuntur II. Botanisches Jarbücher fur Systematik, Pflanzengeschichte und Pflanzengeographie 27: 86-220.

THUNBERG, C.P. 1823. Flora capensis, ed. 2. Cotta, Stuttgart. 